\title{
Cultivating Civic Generosity in Elementary Youth across \\ Glocal Cultures, Ecologies, \& Generations
}

Laura B. Liu

Indiana University-Bloomington

\begin{abstract}
This research explores cultivation of civic generosity in elementary youth as a cultural, ecological, generational practice developing global-local connections and enhanced by artsbased pedagogies, including reading, creating, and sharing children's books. In this study, 2nd grade students across two public school contexts (rural university-affiliated and rural lowincome) reflect on learning generosity from a grandparent/parent to create a children's book presented in a public library. This study draws upon perspectives of participating elementary school teachers, administrators, and librarians to understand how the curricula and their partnerships enhanced student understanding, appreciation, and expression of generosity as a glocal civic practice.
\end{abstract}

Liu, L.B. (2018). Cultivating civic generosity in elementary youth across cultures, ecologies, and generations. In G. Onchwari and J. Keengwe's (Eds.) Handbook of Research on Pedagogies and Cultural Considerations for Young English Language Learners, pp. 396-410. IGI Global. 


\section{INTRODUCTION}

This research explores cultivation of civic generosity in elementary youth as a cultural, ecological, generational practice developing global-local ( glocal) connections and enhanced by arts-based pedagogies, including reading, creating, and sharing children's books. In this study, 2nd grade students across three public school contexts (university-affiliated; urban low-income; rural low-income) reflect on learning generosity from a grandparent/parent and create their own children's books presented in a public library as a practice of placemaking in a shared civic space. This study draws upon perspectives of participating elementary school teachers,

administrators, and librarians to understand if and how the generosity curricula enhanced student understanding, appreciation, and expression of generosity as a glocal civic practice. Connections will be made for how this study of a glocal civics pedagogical model may be relevant for teachers of English Language Learners (ELLs), including how children's literature can support meaning-making. In a post-No Child Left Behind (NCLB) era, it is surprising to find our current U.S. administration veering toward a 'No Minority Allowed In' era. As the civic soil of our glocal communities, teachers play a vital role in supporting individual and shared glocal connection and growth.

\section{THEORETICAL FRAMEWORK}

This research is framed by three pillars of theoretical thought: (1) glocalization as the interchange between the global and the local; (2) civic generosity as cultural, ecological, and generational; and (3) placemaking as a practice of making a space a home for diverse groups. This framework provides the foundation for exploring glocal civic generosity as a vital form of $21^{\text {st }}$ century placemaking, and how arts-based pedagogical approaches enhance youth learning. A 
summary of the generosity curricula implemented across two $2^{\text {nd }}$ grade classrooms in different contexts will follow a discussion of the three pillars of this theoretical framework.

\section{Glocalization}

Dochakuka, or glocalization, first used in Japan in the field of business, is translated literally as land (do), arrive (chaku), and process of ( $k a)$ (Dumitrescu \& Vinerean, 2010). This term was popularized in the U.S. by University of Pittsburgh Professor Roland Robertson in the Harvard Business Review in the 1980s (Dumitrescu \& Vinerean, 2010), and refers to the copresence of universalizing and particularizing tendencies (Khondker, 2004). Kahn (2014) reflects that mixed positive and negative feelings about the global in local spaces are complex, particularly as the glocal is more than a "purely individuated, psychological phenomenon," but is also "social and spatial ... embodied connected ... shared" (McKay, 2014, p. 22). Glocalization results in the blending of identities, particularly along "boundaries of nation-states, nationalities, and ethnicities" (McKay, 2014, p. 22). In education, glocalization supports student participation in global exchange, while maintaining expression of local cultures, languages, philosophies, and ecologies. This can be challenging in light of the global standardization movement leading to a loss of diversity, a trend that calls for more glocal ways of being along with policies for individuals, cultures, and regions (Brooks \& Normore, 2008; Spring, 2008).

Globalization scholar and Economics Nobel Prize winner, Joseph Stiglitz (2003), reflects that during his time serving at the World Bank, that he "saw firsthand the devastating effect that globalization can have on developing countries, and especially the poor within those countries" (ix). Stiglitz (2003) describes globalization as the removal of free trade barriers to connect global economies, and then adds that globalization can "be a force for good," if change is brought to the practice of developed nations imposing policies on less developed nations (ix). Glocalization, as Liu, L.B. (2018). Cultivating civic generosity in elementary youth across cultures, ecologies, and generations. In G. Onchwari and J. Keengwe's (Eds.) Handbook of Research on Pedagogies and Cultural Considerations for Young English Language Learners, pp. 396-410. IGI Global. 
mutually beneficial interaction and regard among the global and local, is a conceptual attempt to move toward the practiced change that Stiglitz was requiring here. In theory, glocalization keeps healthy trade fluid across borders, yet minimizes unhealthy impositions of the global on the local. In education contexts, this means supporting both global and local students to receive the support needed to do well and find meaningful ways to contribute to the glocal societies they are part of. While power dynamics can shift within global-local contexts, the principle remains to balance a healthy exchange. Teaiwa (2014) articulates this well in her encouragement for geopolitical powers to be "as interested in what they can learn from the Pacific as in what they can gain from dominating it" (p. 68), and for Pacific Islanders to "construct their own representations and articulate their own knowledge approaches," particularly regarding "placebased claims of cultural identity, political sovereignty, and self-determination" (p. 69). There is much the global can and needs to learn from the local. Conversely, as the global shares ideas and resources with the local, this sharing ideally would come without imposing their own perspectives and rules.

\section{GENEROSITY}

\section{Generosity as cultural}

Cultivating glocal civic generosity becomes easier in realizing that civilizations across languages, regions, and time have a root concept for this vital civic virtue. In ancient Greek society, generosus held the connotation of giving from a position of abundance and nobility, often without expectation of receiving in return. In contrast, in Confucian heritage, shu (恕) recognizes giving and receiving as key processes involved in generosity. Ubuntu, a Nguni Bantu term from southern Africa, specifies giving what is good or truly needed, as an act of kindness. This term has continued to pave the foundation for civic life, as Archbishop Desmond Tutu Liu, L.B. (2018). Cultivating civic generosity in elementary youth across cultures, ecologies, and generations. In G. Onchwari and J. Keengwe's (Eds.) Handbook of Research on Pedagogies and Cultural Considerations for Young English Language Learners, pp. 396-410. IGI Global. 
highlights we belong to a greater whole and cannot exist in isolation (Kubow \& Liu, 2015; Tutu, 1999). In Zulu, “umuntu ngumentu ngabantu” translates as "a person is a person through other people" also describes the civic belief behind the concept of Ubuntu (Kubow, 2007, p. 313). In ancient Confucian culture, ren (仁), often translated as human benevolence, is composed of two Chinese characters: ren (人), human, and $\operatorname{er}$ (二), two to visually express the idea that to be human is to be human together. Generosity is a foundational pillar for ren (仁), along with trustworthiness, deference, tolerance, and diligence (Analects, 17:6, as cited in Yeo, 2008, p. 379). Confucius popularized the term around $500 \mathrm{BC}$, when China's seven regions were vying for political power (Ames \& Rosemont, 1998). Confucius did not win the political positions he sought, yet established a civic foundation guiding Chinese politics, morality, and education still.

Similarly, Cicero's 44 BC vision for urban centers was to create a civic space for officia, or acts of kindness, and where citizens give and receive to their own and others' benefit. This vision is a common thread maintained in western theoretical foundations for capitalism, perhaps one of the strongest cultures in which American life has developed. In Wealth \& Poverty, Gilder (1993) asserts that capitalism "begins with giving," and that not from "greed, avarice, or even self-love can one expect the rewards of commerce," but from "a regard for the needs of others, a benevolent, outgoing, and courageous temper of mind" (p. 21). As a scholar of capitalism, Gilder (1993) points to "giving, risking, and creating" as "characteristic" traits of the capitalist (p. 21). These assertions are built on previous works by Claude Levi-Strauss (1957), who contends that reciprocity is foundational to all cultures and societies, particularly giving with interest, such that each gift surpasses the value of the previous gift. In relational terms, civic relationships grow. In a society tending to place the natural and development worlds at odds, it is ironic that ecological generosity is framed in similar terms by environmentalists and ecological scientists. 


\section{Generosity as cultural and ecological}

Ecology, a shared treasure across cultures, languages, and regions, both models and encourages generosity. Evidenced by the hospitable behaviors of the Bonobo monkeys (Hansen, 2016), or the regeneration of five new baby trees for every fallen redwood tree (Chin, 2008), ecology is pervasively generous. People tend to be more caring around nature, invoking a value for people and relationships (Mapes, 2009) and providing safe space for introspection away from the urban rush (Weinstein, Przybylski, \& Ryan, 2009). Louv (2011) recognizes "we are made stronger, richer, through our experiences not only with humans but with our other neighbors animals and plants, and the wilder and more native, the better" (p. 111). Louv (2011) suggests including in Putnam's 'social capital' our human-nature connections.

If we view nature as part of a shared ecological-social capital, this view encourages giving back to nature, much as one needs to continue maintaining a bank account. Diamond (2005) addresses this need in Collapse: How Societies Choose to Fail or Succeed, with specific articulations for how humans need to pay proper regard toward nature by giving back. Citing established ranchers, Dick and Jack Hirschy's reflection, "We must take good care of our land, or we will be ruined," Diamond (2005) describes how over planting found in commercial apple orchards can deplete important nutrients, such as nitrogen, from the soil for other plant life to flourish. Conversely, Rachel Carson's Silent Spring highlights the dilemma of adding chemical toxins to the environment, causing a negative impact on both plant and animal life. Carson (1962) writes, "the legend that the herbicides are toxic only to plants and so pose no threat to animal life has been widely disseminated, but unfortunately it is not true. The plant killers 
include a large variety of chemicals that act on animal tissues as well as on vegetation (pp. 3435). In Making Nature Sacred, Gatta (2004) describes the spiritual conditions needed for human behavior to change its current course toward over development and ecological depletion. Gatta (2004) cites Jonathan Edwards and Aldo Leopold to encourage the development of an “ecological conscience" that would "require an enlargement of love, faith, and vision" a development that will not come easily or quickly, due to "humanity's self-serving instincts" (p. $67)$.

Environmentalists across fields and generations remind us of ecology's pervasive generosity, and humanity's tendency toward self-centered exploitation of this. Generosity received from and expressed toward ecology is an increasingly significant need in the shared civic spaces of global and local cultures. Such expressions certainly impact future generations in regards to the ecological health of the planet inherited from our own and previous generations.

\section{Generosity as cultural, ecological, and intergenerational}

Civic expressions of generosity in our glocal communities depend on cultivating practices of generosity across cultures, ecologies, and generations - not only generations in a given moment of time, but also generations across time. Today's youth are inheriting the world adults are currently tending. What cultural and ecological civic legacy will we leave for youth? Louv (2011) highlights connections between ecological and intergenerational generosity, and references Rick Kool, Professor in the School of Environment and Sustainability at Royal Roads University in Victoria, British Columbia. Kool concludes that bringing together groups across generations to care for nature has a positive impact on relationships, and that "in trying to 'heal the world' through restoration, we end up healing ourselves" (Louv, 2011, p. 113). Conversely, 
positive intergenerational connections also have a positive impact on ecological preservation and ultimately restoration. In the International Institute for Environment and Development's (IIED) (2003) Evidence for Hope, the late Anil Agarwal, former Director of the Centre for Science and Environment in India, concluded, "civil society remains weak in two important areas: analyzing scientific and technical issues, crucial in the context of the assault that economic growth will make on natural ecosystems; and, in making policy interventions" (p. 232). Agarwal (2005) adds that ecological generosity, including clean air and water while continuing to develop, is often a

privilege of wealthier areas of the world, yet a glocal civic need in other areas. Sustainable glocal civic generosity that becomes an increasing practice in future generations facing even greater ecological dilemmas, depends upon our caring about global areas of the world experiencing life differently than our local region. If this capacity is crucial for our glocal future, it is one that needs to be taught to youth, particularly in civic institutions, such as elementary schools.

\section{Placemaking}

Placemaking relates to the Greek term, philochoria, or love of place, and involves shaping a place to reflect and maintain its cultural and ecological roots (Noddings, 2013) through the design of physical spaces with aesthetic elements (Flemming, 2007) that invoke community renewal (Zelinka \& Hardin, 2006). Glocal placemaking connects youth with our broader world, while maintaining "appreciation for the particular place" where they live (Noddings, 2013, p. 85). This work inherently involves the natural and human constructed realms, both contributing to the shared ecology of a bioregion. In Exploring a Sense of Place, Harwell and Reynolds (2006), placemaking involves re-inhabiting our spaces by "living-in-place" or "becoming fully 
alive in and with a place" (Berg \& Dasmann, 1977, p. 6). Placemaking is making a space, home, particularly through appreciation of the wealth of cultural and ecological diversity therein.

Storytelling plays a significant role in the work of placemaking. One of the oldest practices of humankind, telling stories helps us shape and be shaped by the cultural and ecological contexts where we live, including the experiences and relationships in those spaces. Storytelling in the $21^{\text {st }}$ century has expanded in function and purpose. In addition to traditional folk tales, fiction stories, non-fiction texts, biographical or auto-biographical texts, ecological storytelling has emerged and has expanded the forms of expressions considered storytelling. Written texts, visual art, and even designed experiences may be shared as stories within a community. Ecological storytelling, for instance, might involve "exploring, mapping, naming, and promoting" a bioregion's unique qualities, then "incorporating them into a bioregional identity, creating a new story for a region" or "an old story, newly realized" (Louv, 2011, p. 122). Whether a classic tale written or read within a context, or an ecological experience grown from the experienced life histories within a region, storytelling plays a key role in placemaking.

This thematic emphasis can be observed in an evolution in children's literature from the Western fairytale canon of the $18^{\text {th }}$ and $19^{\text {th }}$ centuries, toward a greater multicultural, ecological appreciation found in more modern children's books. Children's literature traditionally focused on cultivating character and civility in youth. Aesop's Tales from Ancient Greece in the $6^{\text {th }}$ Century BC cultivated morals. Charles Perrault of $18^{\text {th }}$ Century France, authored classic tales challenging civic blindness to the inner beauty in the Beast or the orphan, as in Beauty and the Beast, Cinderella, and Snow White. In 1812, the Brothers Grimm of Germany published a collection of classic tales, including Cinderella, Rapunzel, Sleeping Beauty, Snow White, and The

Liu, L.B. (2018). Cultivating civic generosity in elementary youth across cultures, ecologies, and generations. In G. Onchwari and J. Keengwe's (Eds.) Handbook of Research on Pedagogies and Cultural Considerations for Young English Language Learners, pp. 396-410. IGI Global. 
Frog Prince. Hans Christian Anderson grew up in a Danish village in the 1800 s and is famous for fairy tales turning a mirror on civic bias and personal vanity, as in The Ugly Duckling who discovers he actually is a lovely swan, or the Wicked Prince who challenges God to war. These stories have cultivated character in youth for generations. Yet, our diverse $21^{\text {st }}$ century youth need opportunity to read children's stories with backgrounds and perspectives shaped by globally diverse contexts. What does character cultivation look like across cultures and languages? How can today's teachers help youth navigate such differences and appreciate the wealth of diversity found in the rich soil of our childhood tales, woven by generations that have come before us? Moreover, how can teachers support youth in becoming authors who can share such stories?

\section{CURRICULUM}

The curriculum developed, implemented, and researched here aims to cultivate glocal civic generosity in students by engaging elementary students in exploring: (1) global and local connection and interchange as entailing generosity; (2) diverse cultural and philosophical views for understanding generosity; (3) inter-generational story sharing as celebrating generosity; (4) ecological representations of this virtue for analyzing generosity; and (5) creating and presenting children's stories in a public library as civic participation of generosity. The informal assessment for each of these was implemented throughout the curriculum, with the researcher inviting the teacher's perspective on what impact the curriculum had on student learning. A final assignment described below served as a summative assessment, though a numerical measurement of students' glocal civic generosity development was not an aim of this work, which is qualitative in nature.

Liu, L.B. (2018). Cultivating civic generosity in elementary youth across cultures, ecologies, and generations. In G. Onchwari and J. Keengwe's (Eds.) Handbook of Research on Pedagogies and Cultural Considerations for Young English Language Learners, pp. 396-410. IGI Global. 
The curriculum emphasized connections among literacy, science, art, and civic skills of generosity, specifically through the use of STEAM-based children's literature to teach literacy, science, art, and civics, simultaneously. Intergenerational and intercultural generosity are explored through texts such as Tokyo Digs a Garden by Jon-Erik Lappano, as well as When Catherine the Great and I Were Eight! by Cari Best in which two grandparents share treasured culture-based traditions with their grandchildren. The curriculum also engaged $2^{\text {nd }}$ grade students in exploring ecological examples of generosity, both through fiction stories, such as Kidogo by Anik McGrory and non-fiction children's texts, such as the Social Lives of Elephants by Mari Schuh. In both STEAM-based texts, the science of generosity is evidenced by the patterned expressions of this virtue, not only by humans, but also in the animal realms.

In building up to the final assignment, students interviewed a grandparent or a parent about their own experiences of generosity, and how they would like to see generosity expressed more around them. Students then reflected on a moment from their own lives when they learned generosity from this grandparent or parent, and developed their own children's story about this memory, with the main characters represented as animals to solidify the connection between ecology and generosity. Students then presented their stories in the public library as a shared civic space, where their generosity stories were put on display for the Thanksgiving season, a holiday well-timed with the curriculum and their civic engagement on the topic of generosity.

\section{METHODS}

\section{Methodology}

This work is a practice of a/r/tography (Irwin et al., 2006; Pourchier, 2010) in that it integrates art, research, and teaching in the same academic space. This aesthetic approach to research enables more complex understandings and deeper appreciation for diverse views on Liu, L.B. (2018). Cultivating civic generosity in elementary youth across cultures, ecologies, and generations. In G. Onchwari and J. Keengwe's (Eds.) Handbook of Research on Pedagogies and Cultural Considerations for Young English Language Learners, pp. 396-410. IGI Global. 
glocal civic generosity, a topic with vested interest across cultures, ecologies, and generations. This "ontological methodology" (Lather, 2009, p. 226) stretches our "comfort zones" (Clarke, 2009, p. 214) in veering from positivistic approaches to knowing (Falmagne, 2009), but takes an aesthetic research approach aiming for "ethical relationality" (Lather, 2009, p. 228) recognizing the "multiplicity, fluidity, and unknowability" within relationships (p. 226). This research invites the artist-teacher-researcher to become "lost" (Lather, 2009, p. 222) to discover new meanings of validity (Falmagne, 2009), and thereby discover greater appreciation across lines of difference.

\section{Research Site \& Participants}

The research is conducted in collaboration with two elementary schools: (1) "EcoSchool," an internationally, culturally, ethnically, linguistically diverse school of predominantly middle income families and affiliated with a university in a university town set within a largely rural state; and (2) "Rise," a culturally, ethnically, linguistically diverse school of predominantly lower income families, within a largely rural state. The findings for this paper focus on these two contexts as a starting point for future research to be conducted in a third or further research sites.

\section{Data Analysis}

This qualitative inquiry (Merriam, 2001) engages a/r/tographical (Irwin et al., 2006; Pourchier, 2010) and grounded theory data analysis (Strauss \& Corbin, 1998) allowing "theory to emerge from the data" (p. 12) through a blend of "inductive" and "deductive" analysis (p. 21). Interviews with participating teachers, administrators, and librarians were analyzed, with student stories and library displays, to consider how participants have understood generosity before this project, and how participants feel the integration of the curricula enhanced student understanding of generosity as an inter-generational, intercultural, and ecological quality. Thematic categories Liu, L.B. (2018). Cultivating civic generosity in elementary youth across cultures, ecologies, and generations. In G. Onchwari and J. Keengwe's (Eds.) Handbook of Research on Pedagogies and Cultural Considerations for Young English Language Learners, pp. 396-410. IGI Global. 
were assigned to data via constant comparative analysis (Glaser \& Strauss, 1967) to identify

conceptual connections and variations across contexts and conditions (Strauss \& Corbin, 1998), and evidence that may "illustrate, support, or challenge theoretical assumptions held prior to the data gathering" (Merriam, 2001, p, 38). Data analysis also considered participant views on how the reading and creation of children's books supported students in understanding and practicing generosity as an inter-generational, intercultural, and ecological quality. This research provides a foundation for future research to expand to international elementary schools to explore convergences and divergences in how generosity is understood across global and local cultures, ecologies, and generations. This text offers emergent insights based on data analyses across two of ultimately the three school sites, where the research is initiated. Data analysis and discussion of emergent findings are key for conducting research that involves ongoing data analysis able to adjust next research steps in response to the findings (Merriam, 2001; Strauss \& Corbin, 1998).

\section{Limitations and Responses}

This study involved implementing curriculum in two $2^{\text {nd }}$ grade classrooms to engage a total of 38 students in the final children's book project. A limitation to this study was the sample size, which included only two teachers, two principals, and four librarians from two public elementary schools, one public university, and one community public library. At the same time, ongoing data analysis (Merriam, 2001; Strauss \& Corbin, 1998) that takes place early in a study and that focuses on a small sample size can strengthen the qualitative inquiry process. This early analysis supports revision in the research focus or process, including changes in how future data is collected or analyzed, or changes in the questions and purposes shaping data collection and analysis.

Liu, L.B. (2018). Cultivating civic generosity in elementary youth across cultures, ecologies, and generations. In G. Onchwari and J. Keengwe's (Eds.) Handbook of Research on Pedagogies and Cultural Considerations for Young English Language Learners, pp. 396-410. IGI Global. 


\section{FINDINGS}

This study explored the impact of this curriculum on student development of civic generosity through the perspectives of (1) teachers and their insight into student learning, (2) administrators and their broader view of school goals and movement toward those goals, and (3) librarians and their understanding of children's literature and learning connections for youth. All participants emphasized the positive impacts the curriculum had on student development. An emergent finding was the importance for continued inquiry to explore more closely if and how English Language Learners (ELLs) benefit from children's infused curricula. In particular, this study evidenced ways elementary youth are able to connect more directly with curricular themes via picture-based children's literature, able to condense complex themes in simpler terms, while simultaneously introducing cultural context content. The extent to which ELLs particularly benefit from these curricular supports is an important topic for future inquiry.

\section{Teacher Perspectives}

All study participants emphasized positive impacts of the curriculum on student development, and each participant highlighted unique aspects of this positive impact. The university-affiliated teacher highlighted how the curricula broadened everyone's views of generosity beyond a "thing" to "time, love, and caring," and how the children's book about the

Bonobo monkey's generosity highlighted an ecological example of this. This teacher highlighted her appreciation in reading Shel Silverstein's The Giving Tree and then planting a radish seed as an example of ecological generosity via nutritional benefits. This teacher observed individual student capacities to model generosity for others, including one student who naturally took the lead in comforting a student with special needs in the classroom. Many students practiced a spirit 
of generosity in asking frequently about the teacher's parent who needed additional health care throughout the year of the study. Such questions demonstrated the capacity for students to show empathy toward their teacher, as well. Unexpected pedagogical challenges included trying to support two English Language Learners in completing the children's book assignment. A peer was able to translate the assignment for one student. The other ELL student's mother, who was more proficient in English, was able to explain the assignments to her daughter at home. These findings raised the researcher's awareness of ways in which the curriculum might support ELL learning, as well as need to scaffold assignments further and provide translation, as needed.

The $2^{\text {nd }}$ grade teacher participant in the lower income school emphasized that the curricular "impact was huge!" She reflected on hearing students spontaneously integrate into conversations with each other the statement, "that was very generous of you!" This teacher reflected that generosity had not been addressed directly in previous curricula, and that this lesson series strengthened the classroom community by providing this focus. She reflected on how previous curricula had encouraged positive behaviors, such as accepting compliments and looking others in the eye while talking with them. The teacher reflected how this curriculum built on these practical skills by inviting students to practice affective capacities, such as empathic consideration for how others might be feeling, as part of developing glocal civic generosity in the classroom. Ecological and inter-generational generosity were relatively new integrations to her $2^{\text {nd }}$ grade curriculum, which each led to thoughtful conversations about how the trees provided acorns for the squirrels, and how their parents and grandparents provided for each of them. The students evidenced delight in making these connections, and were overjoyed to share their generosity stories with each other in a public library presentation of their children's books. The book development provided the students a chance to realize this intergenerational generosity. 
Generosity was highly valued, consistently modeled, and creatively engaged as classroom pedagogy by both $2^{\text {nd }}$ grade teachers. Teacher interest in participating in a glocal civic generosity children's book project may have been a self-selective process that led to studying the work of teachers already developed in this heart capacity. Teacher participants evidenced attitudes, skills, and pedagogies useful for other teachers interested in this work. At the same time, each of the participants highlighted aspects of this curriculum that they otherwise may not have engaged. For Rise elementary students, this curriculum provided more opportunities to engage with ecological and intergenerational generosity. Intercultural generosity already was a strength, as evidenced by the intercultural kinesthetic learning in which all students in the class followed a dance video developed by a Latino educator seeking to engage more youth in school through movement. For the university-affiliated school, ecological generosity was a particular strength, as many stakeholders within and outside the school engaged students in learning about and with nature. Intergenerational generosity was a welcomed focus in both classrooms, where students and teachers expressed appreciation to reflect on generosity learned from grandparents/parents.

\section{Administrator Perspectives}

The Eco-School principal reflected on many ways that ecological generosity was integrated throughout the school's curricula, particularly ways the students were engaged in reflection on how the "Earth gives back" through its natural resources. The principal highlighted ways in which students engaged with generosity via the school's integration of the International Baccalaureate and Primary Years Program curricula, both of which drew upon the school's diverse international heritages in curricula and instruction. Ecological generosity was particularly encouraged via pedagogies involving a growing community garden movement in the school, and a university-led Biology outreach program. She reflected that there might be more explicit Liu, L.B. (2018). Cultivating civic generosity in elementary youth across cultures, ecologies, and generations. In G. Onchwari and J. Keengwe's (Eds.) Handbook of Research on Pedagogies and Cultural Considerations for Young English Language Learners, pp. 396-410. IGI Global. 
discussion of intercultural expressions of generosity, and was interested in exploring this more. Resonating with a theme across administrator and teacher participants, the Eco-School principal emphasized the importance of empathy in allowing a person to put oneself in another's shoes, a skill which results in a generosity of spirit. The importance of this generous spirit was a quality the Eco-School principal greatly emphasized.

The Rise principal emphasized empathy, along with the skills of listening to others with one's full attention, particularly to understand their genuine needs. She reflected that the greatest cultural difference to bridge was across SES levels, and asked "What kind of expectations do we have for a student who sleeps on a couch with the TV on all night? Those are cultural differences between people who are middle class and folks who have nothing." To offer a specific example, the principal shared about a Halloween dance put on by the school for the students. "We charged 50 cents for food or drink, and kids had no money. They did not bring money. Why did we think could charge for those things?" The principal reflected on a spirit of equality and value for all, in which "no one is less or better than anybody," and that everyone in the school is a teacher of something. "The custodian is a teacher. The cafeteria staff is a teacher." A final skill that the principal highlighted as a vital aspect of generosity and the cultivation of a generous atmosphere is understanding and respect for difference and disagreement. "How to have a conversation and disagree with someone appropriately. Those are acts of generosity." The principal emphasized acceptance of another's difference and even their disagreement as an important skill to cultivating in youth practicing glocal civic generosity.

Both administrators expressed a strong value for generosity and described ways generosity was practiced in the school in the formal and informal curricula. As each school supported a unique student population, distinct strengths were articulated for how generosity was Liu, L.B. (2018). Cultivating civic generosity in elementary youth across cultures, ecologies, and generations. In G. Onchwari and J. Keengwe's (Eds.) Handbook of Research on Pedagogies and Cultural Considerations for Young English Language Learners, pp. 396-410. IGI Global. 
conceptualized and practiced more often in terms of either cultural or ecological generosity. Both forms of diversity were highly valued by both schools, while intercultural generosity in terms of SES background was a daily student reality that the Rise principal engaged. Intergenerational generosity in regards to engaging youth with grandparents through formal assignments was a value for both, and perhaps more challenging to attain in the lower income school, due to the more difficult life circumstances students there may face, including single parents, or parents overwhelmed with daily life challenges, such as working long hours or trying to develop a stronger English literacy capacity. The principal of Rise shared ways the school embraced generosity by welcoming contributions from community members offering support to students in need. The Confucian perspective on generosity as both giving and receiving was practiced here.

\section{Librarian Perspectives}

The teacher, principal, and librarian participants all articulated the value of the students' book creation, library book presentations and public display as a valuable exercise in glocal civic placemaking. This library placemaking work connected youth and grandparents in developing the intergenerational generosity stories, and connected youth across cultures in learning about one another's families and cultural heritages. The librarian participant perspectives highlighted ways the library itself is a generous institution, belonging to all members of a civic region, across cultures, nationalities, languages, incomes, and generations. The university librarian participant shared ways the public library reaches out across ability groups and sought to serve as a bridge to create a welcoming space for those who might otherwise not have one, while allowing "others in the community who have not experienced a disability" to have the opportunity to interact with civic members who do have one. This same librarian was the only study participant who articulated generosity as a mutual exchange between giver and receiver and shared her concern Liu, L.B. (2018). Cultivating civic generosity in elementary youth across cultures, ecologies, and generations. In G. Onchwari and J. Keengwe's (Eds.) Handbook of Research on Pedagogies and Cultural Considerations for Young English Language Learners, pp. 396-410. IGI Global. 
for ways the giver might place oneself above the receiver, mistaking altruism for generosity. This librarian encouraged a mutual exchange of generosity that involved giving and receiving. She also highlighted that the most important gift to share is always the gift of one's whole self.

The Rise and Eco-School librarians emphasized ways in which children's literature is able to connect youth with different cultures, ecologies, and generations. This connection is yet another generous function of libraries and the texts therein. The Rise librarian appreciated the resources shared by the community and reflected on the power of books to enrich the lives of children through the sharing of stories and experiences, and that "there is something for everyone" in the library. The Eco-School librarian highlighted two biographical picture books read in classrooms in this study, including Planting the Trees of Kenya, in which Wangari Maathai's tree planting had an inspirational ripple effect in her community, and the advocacy demonstrated in The Tree Lady to plant trees from around the world in San Diego, California, to create the famous public garden, Balboa Park. This librarian reflected that she "loves books where people use their individual talents, especially that do not seem to be written in that didactic manner." She cited a few others texts, some biographical and others fictional and fun, such as Mo Willems' Should I Share My Ice Cream?, in which the stories are "not specifically about generosity," yet demonstrate and encourage generosity.

All librarian interviews evidenced a belief in the power of children's books to cultivate generosity and other civic qualities important in building connections across diverse groups. Moreover, librarian participants were quick to support student presentation and display of their children's books as a natural extension of their work, modeling civic generosity while cultivating it in elementary youth. Glocal civic placemaking was a practice librarians easily engaged with. 


\section{FUTURE RESEARCH DIRECTIONS}

This research is timely, in light of the growing work force of K-12 teachers of ELLs and natural science subjects (Ingersoll, et al., 2017), a trend evidencing need and interest to cultivate global-local civics and a framework for this. The $46 \%$ growth in the teacher workforce observed between 1987 and 2012, largely included ELL and natural science teachers. Moreover, minority teachers grew 104\% in the teacher work force (Ingersoll, et al., 2017). While there is increasing need and interest to cultivate student glocal civic development, questions remain for how to do this, and what kinds of curricula support this, effectively. In particular, this study encourages future research to explore if and how integration of children's literature into elementary curricula supports ELLs and other students on the margins due language, culture, or other factors. Pictures and shorter texts from carefully selected children's books are able to quickly communicate key concepts and complex themes to students struggling to access a new language, as well as struggling readers or other students who feel disconnected from the classroom or school culture. Findings here suggest the positive impact of infusing children's literature into curricula to enhance learning across languages, cultures, and SES backgrounds. Moreover, future research might explore how entire schools experiencing societal marginalization due to culture or class may benefit from children's literature infused curricula on glocal civic generosity across cultures, ecologies, and generations. Questions remain regarding the impact of such curricula on students attending high poverty schools that may be experiencing the greatest societal exclusion.

A related research question recommended is how family-institutional relationships are shaped by and shape curricula focused on glocal civic generosity. In particular, future studies might consider if and how such curricula opens the door for more authentic mutual global-local interchange, and if the global or the local may play a more influential role that does not offer 
adequate space for the other to be expressed and take shape. Moreover, is it even possible for an educational institution to lead the cultivation of civic generosity, a relational virtue at heart? How might the development of this civic virtue be assessed, and how might assessment impact the process of developing a trait requiring selflessness more than the self-advocacy required to do well in schools? In Unequal Childhoods, Lareau (2003) highlights ways that middle-income parents tend to be "very interventionist" (p. 163) and support their children to advocate for their own learning and assessment. In contrast, marginalized parents, whether due to income, language, culture, or other trait, tend to defer to teachers without question. Curriculum aiming to cultivate glocal civic generosity, must practice glocal civic generosity. Such curricula should engage students and their families as central to the knowledge creation process - as co-creators rather than view students (and indirectly their families) as mere recipients of knowledge. McCarthy and Dimitriadis (2000) warn against "globalizing pedagogies" breeding resentment through a "containment discourse," in which cultural groups are "granted their nationalist histories, their knowledges, and alas, their experts" (p. 70). Research on glocal civics must explore the extent to which curricula implemented in educational institutions is able to cultivate generosity across cultures, ecologies, generations, and if family-school disconnects are bridged with meaningful glocal connections as a result of the curricular implementation.

Such curriculum looks toward similar ideals as John Dewey (1916) in his text, Democratic Education. Dewey describes democracy as much "more than a form of government," but a "mode of associated living" that offers greater participation while also requiring consideration for others, which results in "the breaking down of those barriers of class, race, and national territory" preventing those engaged in civic life from "perceiving the full import of their activity" (p. 83). Partnerships across families, schools, and libraries as civic centers is 
encouraged by this study's findings to support expression of Dewey's democratic ideal, a civic generosity resonating with a Confucian 仁 (ren), Greek generosus, and South African Ubuntu, as articulated in the study's framework. Such partnerships offer opportunity for glocal civic placemaking efforts as evidenced herein. Future research might consider if 'silenced' students are empowered by this curriculum to share their voices - particularly marginalized views - and if glocal civic placemaking supports these meaningful connections.

\section{CONCLUSION}

This research responds to a growing global need for cultivating glocal civic generosity, and highlights the central role that education -- as a shared effort among teachers, administrators, librarians, and parents - all play together in this work. This research explores the impact of a curriculum designed to engage elementary youth in the connective work of cultivating glocal civic generosity among global-local dynamics. This study evidences the meaningful impact of this curriculum for cultivating generosity across cultures, ecologies, and generations, as well as the significant role of school-family-library partnerships to support glocal civic placemaking efforts that support this work. This study demonstrates librarian perspectives as closely attuned to this inner work in the lives of youth, and how children's books support this. This study encourages schools and families to partner more closely with librarians to cultivate a glocal civic generosity greatly needed in today's communities. Children's literature, as a rich pedagogical resource for ELLs and all learners, connects youth with their own and others' glocal civic values, including the shared value for generosity and its many diverse cultural, ecological, and generational expressions. This research also invites future studies exploring how children's 
literature can help make civic-science concepts more accessible for ELLs and other readers struggling to access content, due to cultural, linguistic, or other marginalizations.

In light of our growing ecological crisis (Agarwal, 2003; Carson, 1962), AND the powerful potential for ecologically-immersed relationships to restore glocal civic connections (Louv, 2011), this study recognizes the important role for glocal civic curriculum that engages youth in civic-science literary studies, and properly regards the support needed to welcome English Language Learners and other readers on the margins into the glocal civic classroom. Children's literature, read and written by elementary students, can play a key role in this. As evidenced in this study, teachers, principals, and librarians demonstrate interest in supporting glocal civic generosity, and welcome curricular resources that provide helpful materials. This study also highlights the importance for families to play a role in shaping curricular materials, particularly to move toward a balance in the shaping influence of the global and the local.

Liu, L.B. (2018). Cultivating civic generosity in elementary youth across cultures, ecologies, and generations. In G. Onchwari and J. Keengwe's (Eds.) Handbook of Research on Pedagogies and Cultural Considerations for Young English Language Learners, pp. 396-410. IGI Global. 


\section{REFERENCES}

Agarwal, A. (2003). Globalization, civil society and governance: Challenges for the $21^{\text {st }}$ century.

In N. Cross (Ed.), Evidence for hope: the search for sustainable development (pp. 223-

234). Sterling, VA: Earthscan Publications.

Ames, R. T., \& Rosemont, H. (1998). The Analects of Confucius: A Philosophical Translation. New York: Ballantine Pub. Group.

Berg, P., \& Dasmann, R. F. (1977). Reinhabiting California. Ecologist, 7(10), 6.

Carson, R. (1962). Silent Spring. New York: Houghton Mifflin.

Chin, J. (2008). Redwoods. Bel Air, California: Flashpoint.

Clarke, A. E. Getting lost and found and lost and found and lost again with Patti Lather. Frontiers: A Journal of Women Studies (30)1, 212-221.

Dewey, J. (1916). Democracy and education. New York: Macmillan.

Dumitrescu, L. \& Vinerean, S. (2010). The glocal strategy of global brands. Studies in Business and Economics 5(3), 147-155.

Falmagne, R.J. (2009). Deconstruction and the problematics of social engagement: Fertile tensions. Frontiers: A Journal of Women Studies (30)1, 204-211.

Gatta, J. (2004). Making Nature Sacred: Literature, Religion, and Environment in American

Liu, L.B. (2018). Cultivating civic generosity in elementary youth across cultures, ecologies, and generations. In G. Onchwari and J. Keengwe's (Eds.) Handbook of Research on Pedagogies and Cultural Considerations for Young English Language Learners, pp. 396-410. IGI Global. 
from the Puritans to the Present. Oxford: Oxford University Press.

Gilder, G. (1993). Wealth \& Poverty. Basic Books: ICS Press.

Hansen, G. (2015). Bonobos. Minneapolis: Abdo Kids.

Harwell, K. \& Reynolds, J. (2006). Exploring a Sense of Place: How to Create Your Own Local Program for Reconnecting with Nature. Palo Alto: Conexions.

Ingersoll, R., Merrill, L., Owens, C., \& Zukerberg, A. (2017). A Quarter Century of Changes in the Elementary and Secondary Teaching Force: From 1987 to 2012. NCES. Retrieved on 04/14/17 from: https://nces.ed.gov/pubsearch/pubsinfo.asp?pubid=2017092

Irwin, R.L., Beer, R., Springgay, S., Grauer, K., Xiong, G., \& Bickel, B. (2006, June). The rhizomatic relations of a/r/tography. Studies in Art Education.

Kahn, H.E. (2014). Framing the Global: Entry Points for Research. Bloomington: Indiana University Press.

Kubow, P.K., \& Liu, L.B. (2015). Human well-being: Cultivating civic connectivity across global-local (glocal) spaces. Indiana University Grand Challenge Preliminary Proposal. Retrieved from: http://education.indiana.edu/ciedr/Grand\%20Challenge.php

Lather, P. (2009). Getting lost: Feminist efforts toward a double(d) science. Frontiers: A Journal of Women Studies (30)1, 222-230.

Liu, L.B. (2018). Cultivating civic generosity in elementary youth across cultures, ecologies, and generations. In G. Onchwari and J. Keengwe's (Eds.) Handbook of Research on Pedagogies and Cultural Considerations for Young English Language Learners, pp. 396-410. IGI Global. 
Lareau, A. (2003). Unequal childhoods: Class, race, and family life. Berkeley: University of California Press.

Levi-Strauss, C. (1957). Reciprocity, the essence of social life. In Closer \& Rosenberg (Eds.), Sociological theory (pp. 84-94). New York: Macmillan.

Louv, R. (2011). The Nature Principle: Human Restoration and the End of the Nature-Deficit Disorder. New York: Workman Publishing.

Mapes, D. (2009, October 14). "Looking at Nature Makes You Nicer,” MSNBC. Retrieved from: http://www. msnbc.msn.com/id/33243959/ns/health-behavior.

McCarthy, C., \& Dimitriadis, G. (2000). Globalizing pedagogies: Power, resentment, and the renarration of difference. In R. Mahalingam, \& C. McCarthy (Eds.) Multicultural curriculum: New directions for social theory, practice, and policy (pp. 70-84). New York:

Routledge.

McCay, D. (2014). Affect: Making the global through care. In H.E. Kahn's (Ed.). Framing the global: Entry points for research, (pp. 18-36). Bloomington: Indiana University Press.

Merriam, S (2001). Qualitative research and case study applications in education. San Francisco:

Jossey-Bass.

Liu, L.B. (2018). Cultivating civic generosity in elementary youth across cultures, ecologies, and generations. In G. Onchwari and J. Keengwe's (Eds.) Handbook of Research on Pedagogies and Cultural Considerations for Young English Language Learners, pp. 396-410. IGI Global. 
Noddings, N. (2013). Education and Democracy in the 21st Century. New York: Teachers College Press.

Pourchier, N.M. (2010). Art as inquiry: A book review of being with a/r/tography. The Qualitative Report, 15(3), 740-745.

Stiglitiz, J.E. (2003). Globalization and its discontents. New York: Norton \& Company.

Strauss, A., \& Corbin, J. (1998). Basics of qualitative research: Techniques and procedures for developing grounded theory. Thousand Oaks, CA: Sage Publications.

Teaiwa, K. M. (2014). Reframing Oceania: Lessons from Pacific Studies. In H. E. Kahn, \& S. Sassen (Ed.) Framing the Global: Entry points for research (pp. 67-70). Bloomington: Indiana University Press.

Tutu, D. (1999). No Future Without Forgiveness. Image Publishers.

Weinstein, N., Przybylski, A., \& Ryan, R. (2009). Can nature make us more caring? Effects of immersion in nature on intrinsic aspirations and generosity. Personality and Social Psychology Bulletin, 35(10), 1315-29.

Yeo, K.K. (2008). Musing with Confucius and Paul: Toward a Chinese Christian Theology. Eugene, OR: Cascade Books. 


\section{KEY TERMS AND DEFINITIONS}

Ecological Conscience: The reflective and even spiritual capacities needed for human behavior to change its current course toward over development and ecological depletion (Gatta, 2004). Generosity: In ancient Greek society, generosus implies giving from a position of abundance and nobility, often without expectation of receiving in return. In Confucian heritage, shu (恕) includes giving and receiving as key to generosity. Ubuntu, a Nguni Bantu term from southern Africa, specifies giving what is good or needed, as an act of kindness.

Generosus: A Greek term for generosity, with the connotation of giving from a position of abundance and nobility, often without expectation of receiving in return

Glocal Civic Generosity: Interchange between the global and the local that results in generosity across cultures, ecologies, and generations; often results in an important form of $21^{\text {st }}$ century placemaking involving arts-based educational approaches playing a civic connective role.

Glocalization: Dochakuka, or glocalization, first used in Japan in the field of business, is translated literally as land (do), arrive (chaku), and process of $(\mathrm{ka})$ (Dumitrescu \& Vinerean, 2010). This term was popularized in the U.S. by University of Pittsburgh Professor Roland Robertson in the Harvard Business Review in the 1980s (Dumitrescu \& Vinerean, 2010), and refers to the co-presence of universalizing and particularizing tendencies (Khondker, 2004).

Glocal Placemaking: Glocal placemaking connects our youth with our broader world, while maintaining "appreciation for the particular place" where they live (Noddings, 2013, p. 85). 
Placemaking: Placemaking relates to the Greek term, philochoria, or love of place, and involves shaping a place to reflect its unique cultural and ecological aspects (Noddings, 2013) particularly to bring about community renewal (Zelinka \& Hardin, 2006).

Ren (仁): In ancient Confucian culture, ren (仁), often translated as human benevolence, is composed of two Chinese characters: ren (人), human, and $\operatorname{er}$ (二), two, to express that to be human is to be human together. Generosity is foundational for ren (仁), with trustworthiness, deference, tolerance, and diligence (Analects, 17:6, as cited in Yeo, 2008, p. 379).

Shu (恕): Shu (恕), or generosity, emphasizes giving and receiving in Confucian heritage.

Ubuntu: Ubuntu, a Nguni Bantu term from southern Africa, specifies giving what is good or truly needed, as an act of kindness (Kubow \& Liu, 2015). This term has continued to pave the foundation for civic life, as Archbishop Desmond Tutu highlights we belong to a greater whole (1999) and cannot exist in isolation (Tutu, 2008).

Liu, L.B. (2018). Cultivating civic generosity in elementary youth across cultures, ecologies, and generations. In G. Onchwari and J. Keengwe's (Eds.) Handbook of Research on Pedagogies and Cultural Considerations for Young English Language Learners, pp. 396-410. IGI Global. 